\title{
Dietary crude oil exposure during sexual maturation induces hepatic mixed function oxygenase (CYP1A) activity at very low environmental temperatures in Polar cod Boreogadus saida
}

\author{
S. G. George ${ }^{1}$, J. S. Christiansen ${ }^{2}$, B. Killie ${ }^{3}$, J. Wright $^{1}$ \\ ${ }^{1}$ NERC Unit of Aquatic Biochemistry, University of Stirling, Stirling FK9 4LA, Scotland, UK \\ ${ }^{2}$ Norwegian College of Fishery Science, University of Tromse, N-9000 Tromse, Norway \\ ${ }^{3}$ Akvaplan-NIVA AB, PO Box 735, N-9001 Tromse, Norway
}

\begin{abstract}
Previous studies have indicated that hydrocarbon induction of the hepatic microsomal monooxygenase Cytochrome P4501A (CYP1A) is attentuated in certain species of fish by low temperature and in sexually mature female fish by estradiol. This enzyme is used as a biomarker for petroleum hydrocarbon exposure, and with impending oil exploration of the Arctic, in particular the Barents Sea, the current studies were carried out to establish the nature of the response of hepatic CYP1A to dietary petroleum hydrocarbon injestion in Polar cod at their natural environmental temperatures during the breeding season. Polar cod Boreogadus saida maintained at $0^{\circ} \mathrm{C}$ contain a hepatic CYP1A which displays immunochemical and nucleotide homology with other piscine CYP1As and displays typical transcriptional induction by B-napthoflavone or crude mineral oil. The enzyme is induced in both male and female fish fed artificial diets contaminated by crude oil during the period of sexual maturation despite an overall suppression of activity in female fish and a cessation of feeding for $3 \mathrm{wk}$ immediately prior to spawning. The results indicate that use of CYP1A measurements in this species for biomonitoring oil exploration and production in the Arctic environment is a valid procedure.
\end{abstract}

KEY WORDS: Polar cod C Crude oil - Diet - Induction - CYP1A Environmental monitoring

The mixed function oxygenase cytochrome P450 1A (CYP1A) of vertebrates catalyses the hydroxylation of polyaromatic hydrocarbons (PAHs) such as benzo(a)pyrene [arylhydrocarbon hydroxylase (AHH) activityl and $O$-dealkylation of synthetic substrates such as ethoxyresorufin [ethoxyresorufin O-de-ethylase (EROD) activity]. Constitutive levels of the enzyme are very low; however, higher levels are characteristically induced by exposure of the animal to PAHs and polychlorinated biphenyls (PCBs). This inductive response of fish hepatic CYP1A to PAHs and PCBs provides a sensitive sub-lethal method of monitoring the environ- mental bioavailability and impact of these pollutants (reviewed by Payne et al. 1987, Stegeman \& Lech 1991, Goksoyr \& Forlin 1992). The response to crude oils, diesel oils, diesel-based drill muds and petroleum has been calibrated experimentally (Kuralec et al. 1977 , Leaver et al. 1988, Goksoyr et al. 1991) and has been validated by field studies for a number of finfish species including dab, flounder, killifish, plaice, rainbow trout and scup (Payne \& Penrose 1975, Payne et al. 1987, Leaver et al. 1988, Elskus \& Stegeman 1989, Sulaiman et al. 1991, Goksoyr \& Forlin 1992),

Studies with temperate-water fish species have demonstrated a compensatory increase in CYP1A levels with adaptation to low temperature $\left(5\right.$ to $6^{\circ} \mathrm{C}$, cf. 15 to $17^{\circ} \mathrm{C}$ ) (e.g. Koivusaari \& Andersson 1984, Carpenter et al. 1990, George et al. 1990, Kloepper-Sams \& Stegeman 1992) and that at low temperatures the inductive response may be substantially lower or absent (see reviews by Anderson \& Forlin 1992, Stegeman \& Hahn 1994). Thus potential use of hepatic CYP1A induction in Arctic species such as Polar cod Boreogadus saida, which live at environmental temperatures of 0 to $6^{\circ} \mathrm{C}$, as a method for environmental biomonitoring of petroleum hydrocarbon impact in Arctic waters requires experimental verification of the inductive phenomenon. Moreover, at Arctic environmental temperatures, uptake of petroleum might be so slow from natural routes of exposure, water or diet, that systemic PAH levels are too low for practical detection of a measurable response by the hepatic CYP1A system.

There are also conflicting reports on the ability of PAHs and PCBs to induce CYP1A activity in sexually mature females in different fish species. In experimental studies where sexual maturation was induced by treatment with estradiol, Vodicnik \& Lech (1983) 
reported that EROD activity of trout was induced by the prototypical inducer $\beta$-naphthoflavone (BNF), whilst Elskus et al. (1991) reported no measurable induction in Fundulus heteroclitus, which was attributed to an estradiol-mediated pre-translational suppression of CYP1A expression.

In the present study we have demonstrated that Polar cod possess a hepatic CYP1A homologous to that of other fish of approximately $58 \mathrm{kDa}$ and that it is transcriptionally induced by common CYP1A inducers (BNF or crude mineral oil) at $0^{\circ} \mathrm{C}$ and have shown that it is also induced in both male and female fish by longterm (52 d) exposure to dietary crude oil during the period of sexual maturation.

Methods and materials. Fish, collection, exposures and tissue sampling: For establishment of baseline data, Polar cod were caught by trawl from cruise stations in the Barents and Pechora Seas (ca $69^{\circ} \mathrm{N}_{\text {i }}$ see Table 1) in December 1992 and off the Svalbard archipelago $\left(78^{\circ} \mathrm{N}\right)$ in September 1993, sacrificed and livers freeze-clamped in liquid nitrogen on ship. For experimental treatments fish were transported live to the research facilities at Tromsø and were adapted to laboratory conditions by maintenance in sea water aquaria on artificial diets for 3 mo before experimentation as described elsewhere (Christiansen \& George in press).

For characterisation of the inductive response of CYP1A, individuals were injected intraperitoneally with $2 \mathrm{ml}$ crude oil (Oseberg C) $\mathrm{kg}^{-1}$ or $50 \mathrm{mg} \mathrm{BNF} \mathrm{g}^{-1}$ (100 $\mathrm{mg} \mathrm{ml}^{-1}$ in corn oil) and maintained with feeding in a recirculating aquarium at $0^{\circ} \mathrm{C}$. They were sacrificed 10 or $21 \mathrm{~d}$ post injection and livers freezeclamped.

Feeding experiments were carried out as described in detail elsewhere (Christiansen \& George in press). Briefly, groups of fish were maintained at natural temperatures $\left(6\right.$ to $3^{\circ} \mathrm{C}$ ) and photoperiod (4 to $10 \mathrm{~h}$ light $\mathrm{d}^{-1}$ ) for $70^{\circ} \mathrm{N}$ and were fed twice weekly in excess with control or oil-contaminated diets (ca $200 \mathrm{mg}$ crude oil $\mathrm{kg}^{-1}$ diet) from 3 December 1993 to 25 January 1994. Oil intake was estimated by addition of Ballitoni glass beads to the feed and counting beads in $\mathrm{x}$-ray photographs of the fish. During the experiment the fish became sexually mature and ceased feeding on 25 January. They were sacrificed 21 d after cessation of feeding (15 February); the livers were removed and freeze-clamped in liquid nitrogen.

All liver samples were shipped in dry ice to Stirling where they were stored at $-80^{\circ} \mathrm{C}$ for up to $2 \mathrm{wk}$ before analysis.

Analyses: Analyses were carried out by procedures established in our laboratory and described previously (George et al. 1990, Sulaiman et al. 1991, Leaver et al. 1993). For enzyme analysis, livers were homogenised in ice-cold buffered sucrose $(20 \% \mathrm{w} / \mathrm{v}$ homogenate), microsomal fractions were prepared by differential centrifugation (pelleted between $2 \times 10^{5}$ and $6 \times 10^{6} \times g$ min) and the characteristic EROD activity of CYP1A in the resuspended microsomes was determined immediately by kinetic fluorescence assay using a resorufin standard with an apparent extinction coefficient of 24 . Activities were corrected arithmetically for an extinction coefficient of 73 for pure resorufin. Optimal rates of activity were obtained at $25^{\circ} \mathrm{C}$ and assays were performed at this temperature. Protein content was determined by the colorimetric procedure of Lowry et al. (1951) using bovine serum albumin as standard, and aliquots of the microsomal fractions were stored frozen for subsequent immunochemical analysis of the content of CYP1A protein by Western blot analysis. For Western blot analysis of CYP1A protein, the detergentsolubilised microsomal proteins were separated according to molecular size in $10 \%$ polyacrylamide gels by SDS-PAGE ( $25 \mu \mathrm{g}$ protein per lane) and blotted to nitrocellulose membranes. CYP1A was then labelled by reaction with a specific monoclonal antibody towards scup P-450E (kindly provided by Dr J. Stegeman, WHOI, Woods Hole, MA, USA) or a polyclonal antibody towards trout P450BNF (kindly provided by M. Celander, Univ. of Göteborg, Sweden) and then visualised by reaction with an alkaline-phosphataselabelled secondary antibody (essentially as described for plaice glucuronosyltransferase by Clarke et al. 1992). For Northern blot analysis of CYP1A mRNA, total RNA was extracted from ca $100 \mathrm{mg}$ samples of frozen liver, fractionated by electrophoresis in $1 \%$ agarose gels, transferred to nylon and detected by hybridisation to a ${ }^{32} \mathrm{P}$-labelled probe prepared from the entire coding region of plaice P4501A cDNA (PLP450BNF2) as described previously (Leaver et al. 1993).

Results and discussion. Polar cod CYP1A analysis, baseline data for the Barents Sea area: Sample sites are shown in Fig. 1 and fish parameters and hepatic EROD activities are given in Table 1 . None of these fish had significantly mature gonads.

For the December 1992 cruise in the Barents/ Pechora Sea area, the fish lengths and liver weights were significantly smaller at Stn 108 (see Table 1) than other stations ( $p<0.05,2$-way ANOVA) and the fish differed in weights; however, there were no significant differences in hepatosomatic indices and the hepatic CYP1A (EROD) activities were not significantly different in fish from the 3 stations, nor was there any positive correlation between EROD activities and size of individual fish. Fish from the September 1993 sampling near Svalbard were approximately twice the weight and approaching sexual development and the hepatosomatic indices were slightly lower. Hepatic 


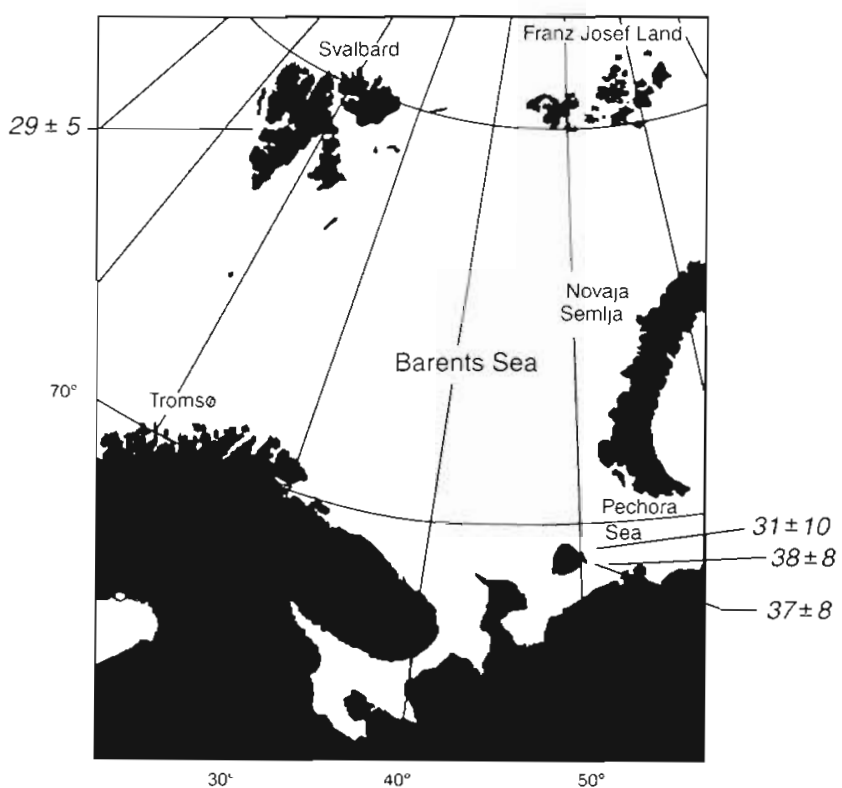

Fig. 1. The Barents Sea showing sampling stations and hepatic CYP1A EROD activities for Polar cod Boreogadus saida caught at these stations. Activities (in italics) were determined as described in 'Methods and materials' and are

given as pmol $\mathrm{min}^{-1} \mathrm{mg}^{-1}$ microsomal protein $( \pm$ SEM)

EROD activities were not significantly different from those in fish obtained from the Barents Sea in the previous cruise.

There are no data on possible population differences between Polar cod stocks in the Barents Sea area, and the present data do not provide evidence for differences. These results indicate that fish from the different stations had a uniform exposure history, and their hepatic EROD activities are comparable with those of fish from non-polluted environments (see e.g. Elskus \& Stegeman 1989, George et al. 1990) and are consistent with these fish being non-induced.

Experimental induction of hepatic CYP1A at low temperatures: Due to the logistic difficulties of transporting Polar cod to the laboratory and adapting them to captivity only very limited numbers of fish from the first cruise were successfully adapted to laboratory conditions and only single fish were available for characterisation of the inductive response of hepatic CYP1A at this very low temperature $\left(0^{\circ} \mathrm{C}\right)$. This experiment showed that hepatic CYP1A activity (EROD) of Polar cod is strongly induced (8- to 13 -fold) by BNF or crude oil injection (Fig. 2); Western blot analysis of hepatic microsomes with antisera to CYP1A of 2 other fish species showed that a homologous protein of approximately $58 \mathrm{kDa}$ molecular weight was induced (Fig. 3), whilst Northern blot analysis using the entire coding region of plaice CYP1A CDNA as a probe at low hybridisation stringency showed that, in common with the known regulatory characteristics of CYP1A in other species, induction was also transcriptional in Polar cod.

Effect of dietary crude oil ingestion on hepatic CYP1A activities: Fish under natural conditions of water temperature and photoperiod were maintained on artificial diets with varying degrees of crude oil contamination as described in detail elsewhere (Christiansen \& George in press). With the exception of 4 fish, 3 of which died during the course of the experiment, all the fish became sexually mature during the course of the experimental period. In January, $52 \mathrm{~d}$ after commencement of the experiment, they ceased feeding until some fish started spawning on Day 72. All fish were therefore sacrificed at this time, livers removed and freeze-clamped and organ parameters determined. Hepatic microsomal protein content and EROD activities were determined in Stirling for all samples and the summarised data are given in Table 2 . CYP1A protein content was also determined in some samples by Western blot analysis.

Considering the results for control fish: at the commencement of the experiment the gonads were only slightly developed, allowing sexes to be distinguished, and whilst the EROD activities appeared to be lower in the females they were not significantly diferent from

Table 1. Boreogadus saida. Sampling station, fish data and hepatic CYP1A EROD activities \pm SEM. HSI: hepatic somatic index, $\%$ body wt. EROD activities are expressed as $\mathrm{g}^{-1}$ liver wet wt or as $\mathrm{mg}^{-1}$ microsomal protein.

\begin{tabular}{|c|c|c|c|c|c|c|c|}
\hline \multirow[t]{2}{*}{ Location } & \multicolumn{4}{|c|}{ Fish } & \multicolumn{3}{|c|}{ Hepatic EROD } \\
\hline & $\begin{array}{l}\text { Length } \\
(\mathrm{mm})\end{array}$ & $\begin{array}{l}\text { Weight } \\
\text { (g) }\end{array}$ & $\begin{array}{l}\text { HSI } \\
(\%)\end{array}$ & $\mathrm{n}$ & $\begin{array}{c}\text { nmol } \\
\min ^{-1} g^{-1}\end{array}$ & $\begin{array}{c}\mathrm{pmol} \\
\mathrm{min}^{-1} \mathrm{mg}^{-1}\end{array}$ & $\mathrm{n}$ \\
\hline \multicolumn{8}{|l|}{ Barents Sea } \\
\hline $69^{\circ} 41^{\prime} N, 51^{\circ} 01^{\prime} E, \operatorname{Stn} 108$ & $136 \pm 2$ & $14.3 \pm 0.8$ & $6.3 \pm 0.6$ & 14 & $2.12 \pm 0.75$ & $31 \pm 10$ & 10 \\
\hline \multicolumn{8}{|l|}{ Pechora Sea } \\
\hline $69^{\circ} 30^{\prime} \mathrm{N}, 51^{\circ} 31^{\prime} \mathrm{E}, \mathrm{Stn} 111$ & $144 \pm 2$ & $17.7 \pm 0.9$ & $6.8 \pm 0.4$ & 13 & $2.34 \pm 0.45$ & $37 \pm 8$ & 9 \\
\hline $69^{\circ} 31^{\prime} N, 53^{\circ} 14^{\prime} E, \operatorname{Stn} 125$ & $152 \pm 5$ & $21.5 \pm 1.8$ & $6.8 \pm 0.5$ & 12 & $2.96 \pm 0.79$ & $38 \pm 8$ & 9 \\
\hline \multicolumn{8}{|l|}{ Svalbard } \\
\hline $78^{\circ} 57^{\prime} \mathrm{N}, 11^{\circ} 9^{\prime} \mathrm{E}$ & - & $51 \pm 6$ & $5.3 \pm 0.4$ & 12 & $2.47 \pm 0.4$ & $29 \pm 5$ & 10 \\
\hline
\end{tabular}




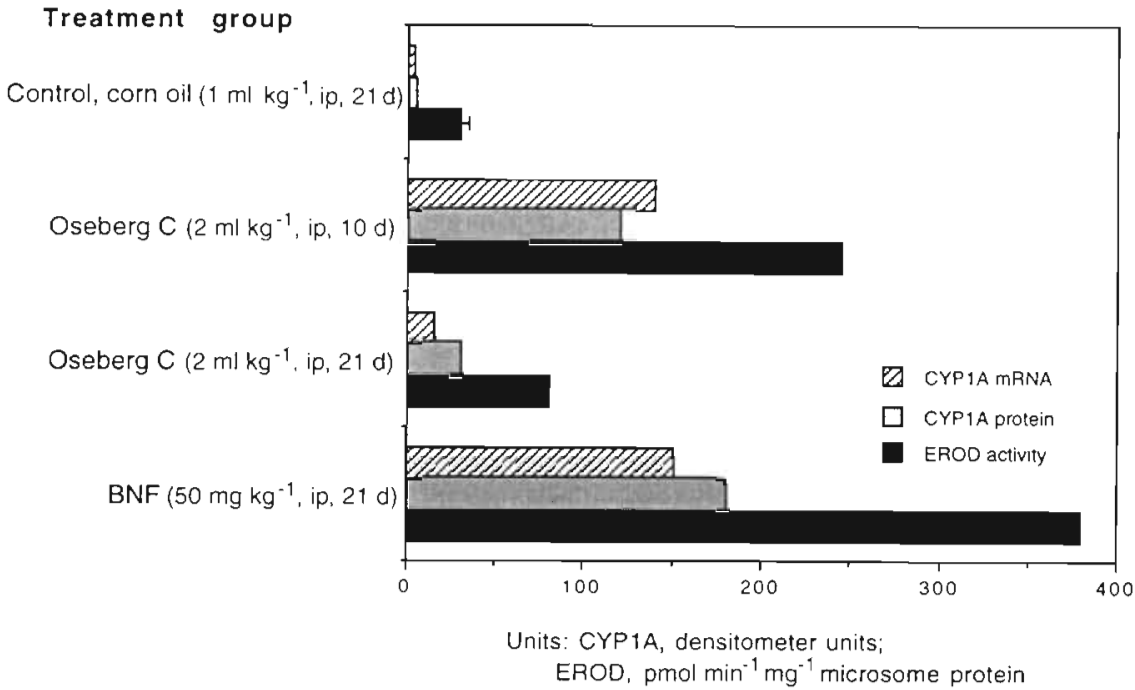

Fig. 2. Boreogadus saida. Induction of hepatic CYP1A and EROD activity in Polar cod by crude oil or a prototypical flavenoid inducer. CYP1A mRNA. was determined with a plaice CYP1A1 CDNA probe, CYP1A with MAb 1-12-3 towards scup CYP1A mRNA and protein, and activity with ethoxyresorufin as substrate as described in 'Methods and materials' those of male fish (Table 2). After maintenance on the non-contaminated diet for $72 \mathrm{~d}$ until sexual maturation, there was a clear sex difference in enzyme activities. In male fish they were slightly lower but not significantly different from those of male fish at the start of the experiment, whilst in female fish the activities were some 3.4 -fold lower $\left(8 \pm 2\right.$ vs $28 \pm 5 \mathrm{pmol} \mathrm{min}^{-1} \mathrm{mg}^{-1}$ microsomal protein). The slight apparent decrease in activity in male fish may be attributed to a temperature compensation whilst that in female fish is clearly due to the sexual maturation process. This sex difference in hepatic CYP1A enzyme activities of reproductively mature female fish has been reported in numerous, but not all, fish species (see reviews of Andersson \& Forlin 1992 and Stegeman \& Hahn 1994) and becomes apparent during the later stages of sexual development.

CYP1A activities in fish fed crude-oil-contaminated diets for a period of $52 \mathrm{~d}$ and assayed after a further

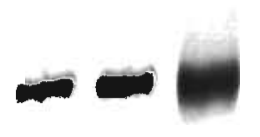

$\begin{array}{ccccc}125111 \quad 108 & 21 d & 21 d & 10 d & \text { STD } \\ \text { Stations } & \text { Oil } & \text { BNF Oil } & \text { BNF } \\ \text { Polar Cod } & & & \text { Trout }\end{array}$

Fig. 3. Boreogadus saida. Western immunoblot of Polar cod microsomes. Lanes contained $30 \mu \mathrm{g}$ microsomal protein. Immunodetection of CYP1A was with MAb 1-12-3 towards scup P450E and alkaline-phosphatase-labelled secondary antibody as described in 'Methods and materials'. STD: BNF-treated rainbow trout microsomes
3 wk assimilation/depuration showed a significant $(\mathrm{p}<$ 0.01 . Student's $t$-test) 5 -fold elevation in both males and females (Table 2), showing that the typical induction of EROD activity following PAH exposure is elicited by crude oil feeding in sexually mature female as well as male Polar cod. When CYP1A protein was determined in representative samples by Western blot analysis, a parallel induction was observed.

The induction of hepatic CYP1A in mature female fish is noteworthy in view of the conflicting reports in other species noted earlier. The present results for Polar cod indicate that under natural conditions of sexual maturation there is no effective suppression of the inductive response in this species.

Quantification of the dietary intake of the fish by an $x$-ray technique enabled estimation of the total crude oil intake by the fish. The total ingested dose ranged from approximately 40 to $250 \mathrm{mg}$ oil $\mathrm{kg}^{-1}$ body weight, i.e. about 4 to $20 \mathrm{mg}$ oil ind. ${ }^{-1}$ over the $52 \mathrm{~d}$ period which represents a relatively low intake rate $(200$ to $950 \mu \mathrm{g} \mathrm{meal}^{-1}$ ). It should be noted that this represents oil intake rather than assimilation and further shows that this biological response is a highly sensitive indicator of exposure. If the total amount of oil injested per fish is plotted against the hepatic EROD activities for both males and females (Fig. 4) there appears to be a positive correlation in both sexes $\left(\mathrm{r}^{2}=0.81\right.$ for males and $r^{2}=0.86$ for females). The data show an apparent sex-dependent difference in the dose-response of the induction, which may be due to a difference in the assimilation of the injested oil, its metabolism or the induction process itself and is worthy of further investigation, especially as it may indicate that the previous, apparently conflicting results of hormonally mediated suppression may be attributable to a pharmacokinetic effect. 
Table 2. Boreogadus saida. Hepatic CYP1A EROD activities of Polar cod fed control or oil-contaminated diets. EROD activities were measured at $25^{\circ} \mathrm{C}$ and are given as means $\pm S E M$. Relative activities are compared with those of immature males at commencement of experiment $(=1.0) . x$-fold induction indicates activities relative to respective control fish at $72 \mathrm{~d}$

\begin{tabular}{|c|c|c|c|c|}
\hline \multirow[t]{2}{*}{ Group } & \multicolumn{4}{|c|}{ CYP1A EROD activity } \\
\hline & $\begin{array}{l}\text { pmol min }{ }^{-1} \mathrm{mg}^{-1} \\
\text { microsomal protein }\end{array}$ & $\begin{array}{l}\text { Relative } \\
\text { activity }\end{array}$ & n & $\begin{array}{c}x \text {-fold } \\
\text { induction }\end{array}$ \\
\hline \multicolumn{5}{|l|}{ Non-contaminated controls } \\
\hline Immature males (at start) & $31 \pm 6$ & $1.0 \pm 0.2$ & 5 & - \\
\hline Immature females (at start) & $28 \pm 5$ & $0.9 \pm 0.15$ & 5 & - \\
\hline Male captive controls ( $72 \mathrm{~d}$ ) & $28 \pm 6$ & $0.9 \pm 0.2$ & 12 & - \\
\hline Female captive controls ( $72 \mathrm{~d}$ ) & $8 \pm 2$ & $0.26 \pm .06$ & 14 & - \\
\hline \multicolumn{5}{|l|}{ Contaminated diets } \\
\hline Males, fed oiled diet $52 \mathrm{~d}$, killed $72 \mathrm{~d}$ & $132 \pm 14$ & $4.3 \pm 0.5$ & 12 & 4.7 \\
\hline Female, fed oiled diet $52 \mathrm{~d}$, killed $72 \mathrm{~d}$ & $42 \pm 6$ & $1.4 \pm 0.2$ & 14 & 5.3 \\
\hline
\end{tabular}

Environmental and practical significance: These data confirm the presence of a CYP1A homologue in Polar cod and show that it is readily inducible by petroleum hydrocarbon exposure at their natural environmental temperature around $0^{\circ} \mathrm{C}$. Thus deleterious effects of potential procarcinogens are potentially just as important at low environmental temperatures; moreover, from the very limited study carried out here the results indicate that compared with temperate-water fish species, the temporal course of the response in Polar cod appears to be extended sufficiently to handle environmental challenges faced by these fish

The enzyme could be induced by long-term dietary exposure to crude oil during the period of sexual maturation in both male and female fish. Even though the fish had ceased feeding for 3 wk before sacrifice, assimilation of food presumably continued and the inductive effect persisted. Thus in their natural environment the effects of ingestion of crude oil appear to be relatively persistent.

Considering the potentially difficult sampling logistics in this remote environment, this study shows that the CYP1A system of the Polar cod responds to contaminant exposure in the same characteristic manner as in other vertebrates and also indicates that the use of hepatic CYP1A measurements in this extremely abundant polar species is both a valid and feasible method for environmental biomonitoring of the planned petroleum exploitation in the Barents Sea area. Preliminary baseline data indicate that the area is presently pristine.

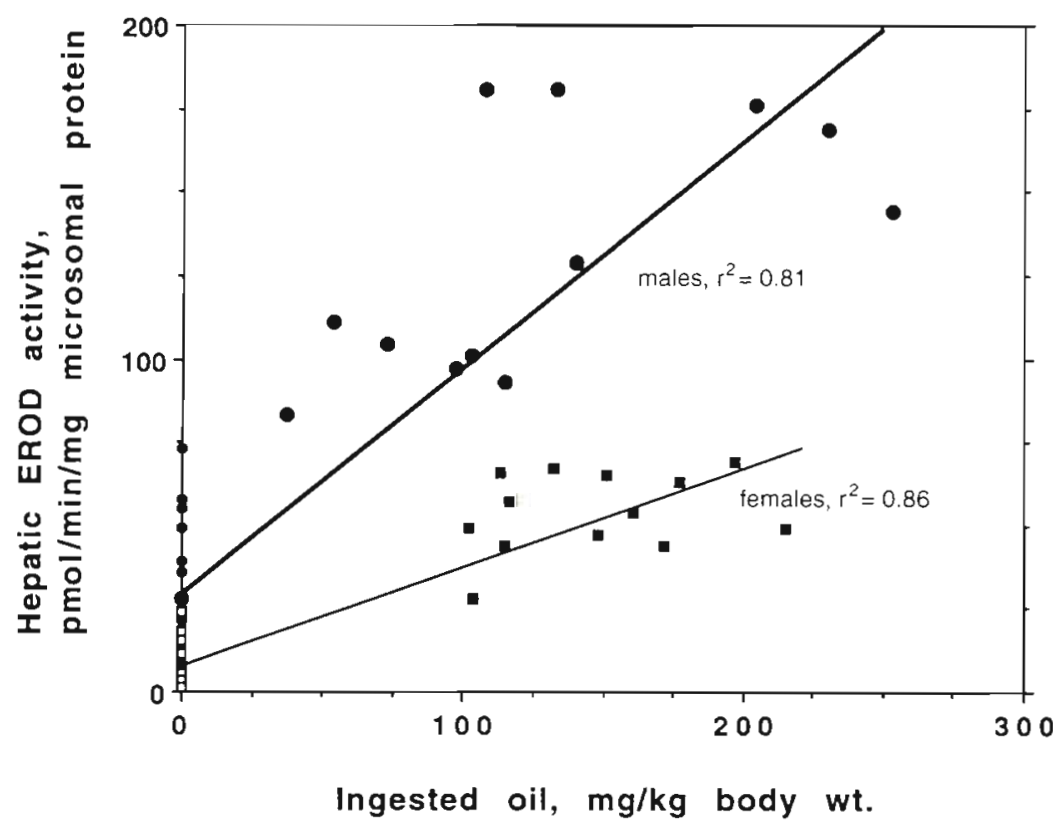

200-400 $\mathrm{mg}$ oil/kg diet, 52 days, $3-6^{\circ} \mathrm{C}$ sacrificed 73 days
- female contaminated - female control

Fig. 4. Boreogadus saida. Relationship between ingested crude oil dose and hepatic EROD activities in Polar cod. Crude oil ingestion was measured by an $\mathrm{x}$-ray technique (Christiansen \& George in press) and EROD activities were determined as described in 'Methods and materials' Regression lines were fitted by 'Cricket Graph' software (Computer Associates, San Diego, CA, USA) 
Acknowledgement. These studies were supported by a contract from Statoil AB to Akvaplan-Niva.

\section{LITERATURE CITED}

Andersson T, Forlin L (1992) Regulation of cytochrome P450 enzyme system in fish. Aquat Toxicol 24:1-20

Carpenter HM, Frederickson LS, Williams DE, Buhler DR, Curtis LR (1990) The effect of thermal acclimation on the activity of arylhydrocarbon hydroxylase in rainbow trout. Comp Biochem Physiol 97 C:127-132

Christiansen JS, George SG (in press) Contamination of food by crude oil affects food preference and growth performance, but not appetite in an Arctic fish, the Polar cod (Boreogadus saida). Polar Biol

Clarke DJ, Burchell B, George S (1992) Differential expression and induction of UDP-glucuronosyltransferase isoforms in hepatic and extrahepatic tissues of a fish: immunochemical and functional characterisation. Toxicol appl Pharmacol 115:130-136

Elskus AA, Singh H, Stegeman JJ (1991) Pre-translational suppression of cytochrome P-4501A expression in the killifish, Fundulus heteroclitus. Comp Biochem Physiol 92C: $223-230$

Elskus AA, Stegeman JJ (1989) Induced cytochrome P450 in Fundulus heterociltus associated with environmental contamination by chlorinated biphenyls and polynuclear aromatic hydrocarbons. Mar environ Res 28:25-28

George S, Young P, Leaver M, Clarke D (1990) Activities of pollutant metabolising and detoxication systems in the liver of the plaice, Pleuronectes platessa: sex and seasonal variations. Comp Biochem Physiol 96C:185-192

Goksoyr A, Forlin L (1992) The cytochrome P450 system in fish, aquatic toxicology and environmental monitoring. Aquat Toxicol 22:287-312

Goksoyr A, Solberg T, Serigstad B (1991) Immunochemical detection of cytochrome P4501A induction in cod larvae and juveniles exposed to a water soluble fraction of North Sea crude oil. Mar Pollut Bull 22:122-127

Kloepper-Sams P. Stegeman JJ (1992) The effect of temperature acclimation on the expression of cytochrome P4501A mRNA and protein in the fish Fundulus heteroclitus. Arch Biochem Biophys 299:38-46

This note was presented by D. S. McLusky (Senior Editorial Advisor), Stirling, UK
Koivusaari U, Andersson T (1984) Partial temperature compensation of hepatic biotransformation enzymes in juvenile rainbow trout (Salmo gairdneri) during the winter warming in spring. Comp Biochem Physiol 78B:223-226

Kurelec B, Britvić S, Rijavec M, Müller WEG, Zahn RK (1977) Benzo(a)pyrene monoxygenase induction in marine fishmolecular response to oil pollution. Mar Biol 44:211-216

Leaver MJ, Burke MD, George SG, Davies JM, Raffaelli D (1988) Induction of Cytochrome P-450 monooxygenase activities in plaice by 'model' inducers and drilling muds. Mar environ Res 24:27-30

Leaver MJ, Pirrit L, George SG (1993) Cytochrome P4501A1 cDNA from plaice (Pleuronectes platessa) and induction of P450 1 A1 mRNA in various tissues by 3-methylcholanthrene and isosafrole. Molec mar Biol Biotechnol 2: $338-345$

Lowry OH, Rosebrough AL, Farr AL, Randle RJ (1951) Protein measurement with the Folin phenol reagent. J biol Chem 193:265-267

Payne JF, Fancey LL, Rahimtula AD, Porter EL (1987) Review and perspective on the use of mixed function oxygenase enzymes in biological monitoring. Comp Biochem Physiol 86C:233-245

Payne JF, Penrose WR (1975) Induction of arylhydrocarbon (benzo(a)pyrene) hydroxylase in fish by petroleum. Bull Environ Contam Toxicol 14:112-116

Stegeman JJ, Hahn M (1994) Biochemistry and molecular biology of monooxygenases: current perspectives on forms, functions and regulation of cytochrome P450 in aquatic species. In: Malins DC, Ostrander GK (eds) Aquatic toxicology, molecular, biochemical and cellular perspectives. Lewis Publ, Boca Raton, p 87-206

Stegeman JJ, Lech JJ (1991) Cytochrome P-450 monooxygenase systems in aquatic species: carcinogen metabolism and biomarkers for pollutant exposure. Environ Health Perspect 90:101-109

Sulaiman N, George S, Burke MD (1991) Sublethal assessment of pollutant impact on flounders in an industrialised estuary using hepatic biochemical indices. Mar Ecol Prog Ser 68:207-212

Vodicnik MJ, Lech JJ (1983) The effect of sex steroids and pregnenolone-16 $\alpha$-carbonitrile on the hepatic microsomal monooxygenase system of rainbow trout. J Steroid Biochem 18:323-328

Manuscript first received: October 20, 1994

Revised version accepted: January 18, 1995 